\title{
Budavári Árpád
}

\section{„Embernek maradni és segíteni” Interjú dr. Sipos Gyula ny. r. vezérőrnaggyal}

\author{
„To stay human and help" \\ Interwiew with ret. pol. major general dr. Gyula Sipos
}

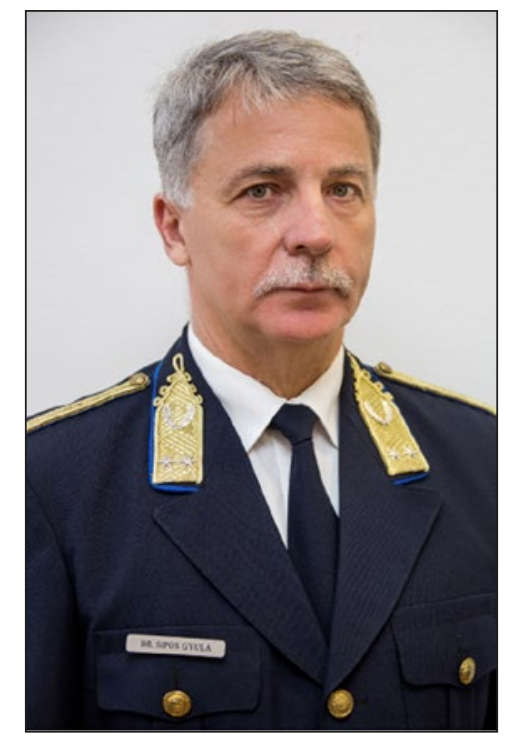

\begin{abstract}
Absztrakt
A szerző a Nemzeti Közszolgálati Egyetem Rendészettudományi Doktori Iskolájának doktoranduszaként készített interjút a 40 éves rendőri pályáját befejező, az elmúlt év november 30 -án nyugdíjba vonult dr. Sipos Gyula ny. r. vezérörnaggyal. Az interjúban megemlékeznek a nyugdíjba vonuló vezető pályájának legfontosabb állomásairól. Arról, hogy mit jelentett a szocializmusban rendörnek lenni, miként élte meg rendőrként a rendszerváltást, a Team Consult vizsgálatot, mi a véleménye a rendőrség pluralizálódásáról, arról, hogy milyen lehetőségei voltak különböző beosztásaiban a problémák kezelésére, hogyan tudta
\end{abstract}


munkájában összekapcsolni a szabálykövetést és az újító szellemet. Tábornok úr kifejti véleményét a centralizált rendőrségről, a rendőrség változásáról, valamint - nyugdíjba vonulása után kapott feladatával kapcsolatban - a rendőrség kommunikációs tevékenységéröl.

Kulcsszavak: interjú, vezetés, rendészettörténet, rendészeti reformok, problémakezelés

\section{Abstract}

The author conducted an interview as a doctoral student of the Doctoral School of Law Enforcement at the University of Public Service, with ret. pol. major general dr. Sipos Gyula. The interview recalls the most important stages in the career of a retiring leader. About what it meant to be a police officer in socialism, how he experienced the regime change as a police officer, the Team Consult investigation, the pluralism of the police, what opportunities he had in different positions to deal with problems, how he could combine rule and innovation in his work. The General expresses his opinion about the centralized police, the change of the police and, in connection with his task after his retirement, the communication activities of the police.

Keywords: interview, leadership, policing history, law enforcement reforms, problem management

Dr. Sipos Gyula ny. r. vezérőrnagy 1980-ban kezdte rendőri pályafutását a Dunaújvárosi Rendőrkapitányságon, 1990-ben pályázat útján nyerte el a kapitányságvezetői beosztást. 1995-től az ORFK-n a bevetésirányítás megújításán dolgozott, 1996-2000 között a Fejér Megyei Rendőr-főkapitányság vezetője, majd 2002-ig az ORFK Gazdasági Főigazgatójának helyettese, 2010-ig gazdasági fóigazgató volt. Ezt követően a Belügyminisztérium Közfoglalkoztatási Helyettes Államtitkárságán kapott pénzügyi-gazdálkodási feladatokat, végül 2015-től nyugdíjba vonulásáig a Zala Megyei Rendőr-főkapitányságot vezette. Személyében a magyar rendőrtársadalom általánosan elismert ikonikus alakja fejezte be rendőri vezetői pályáját. Nyugdíjba vonulása alkalmából Zala Megye Közgyülése a megye díszpolgárává választotta, négy évtizedes, kimagasló szolgálati tevékenysége, valamint példaértékű vezetői munkája elismeréseként pedig a Magyar Érdemrend Tisztikeresztjét vehette át Áder János köztársasági elnöktől. Azonban legalább ennyire büszke arra, ahogy kollégái búcsúztak tőle utolsó munkában töltött napja után: díszsorfallal, vastapssal. Negyven évet átölelő, gazdag pályafutásának tapasztalatairól kérdeztem. 
Tábornok úr! Pályafutásában az évtizedfordulók különös jelentöséggel birhatnak, hiszen 1980-ban lett rendör, 1990-ben kapitányságvezetö, 2000-ben az ORFK egyik meghatározó vezetöje, 2010-ben a közmunkaprogram kiépitésében kapott szerepet, tavaly pedig 40 év rendöri szolgálat után nyugdíjba vonult. Minden ilyen kerek?

Nem mindig volt ilyen kerek! Persze, így visszatekintve akár úgy is tünhet. A pontosítás okán: 2000-ben egyike voltam annak a nyolc megyei főkapitánynak, akit akkor Pintér Sándor belügyminiszter úr felállított, s az akkori ORFK vezetés - Orbán Péter altábornagy úr - adott új feladatot. 2010-ben aztán a kormányváltás már bejáratott forgatókönyve szerint az új kormány belügyminisztere ismét felállított az akkori beosztásomból - ő ismét Pintér Sándor miniszter úr volt. Támogatásával intenzív angol tanulmányokat kezdhettem az Országos Rendőr-fökapitányság Nemzetközi Oktatási Központjában, s ma is hálás vagyok érte, mert e nélkül nem lett volna ilyen magas szintủ angol nyelvtudásom. Aztán 2011 öszén már vártam, hogy mikor olvasom a Magyar Közlönyben, hogy köztársaság elnöki határozattal utamra bocsátanak, de ez nem érkezett meg. Ezzel szemben 2011. szeptember első felében hívott a belügyminiszter úr titkárnője, hogy miniszter úr adott napon, adott órában a tárgyalójában vár. Akkor indult a közfoglalkoztatás programja, s az újonnan alakult közfoglalkoztatási helyettes államtitkárságon kért fel egy feladatra. Ennek a területnek a programtervezési és költségvetési, finanszírozási területén kellett segítenem Papp Károly államtitkár úrnak. Nagyszerü feladat volt!

Ezen a területen 2015 januárjáig dolgoztam, s egy újabb váltással a Zala Megyei Rendőr-főkapitányság vezetését bízta rám belügyminiszter úr és az ORFK vezetése. Ennek a feladatnak 2020. november 30-án vége lett. A felső korhatár elérésével nyugállományba vonultam. Fontos: 2000, aztán 2010, s végül 2020! Azt mondtam egyszer, hogy belügyminiszter úr döntése végigkísérte az aktív pályafutásomat, 10 évente vagy felmentett vagy új feladatot adott.

\section{Mi sarkallta arra, hogy rendör legyen?}

Nem rendőrnek készültem. Az egyetemen töltött évek alatt alakult ki a gondolat. Volt egy praktikus oka, tudniillik akkor a végzős diplomások csak kötelező pályázati rendszerben helyezkedhettek el tanulmányaik befejezését követően, és nem akartam Dunaújvárosból elkerülni, de persze volt valami romantikus vágyódás az igazság eszméje iránt is. Ezt erősítette gyerekkori barátom is, akivel együtt laktam az egyetemi éveim egy részében, ő jogot tanult és bírónak készült. 
Mit jelentett rendörnek lenni a végéhez közeledö szocializmusban? Meddig tartott a szakma a rendörségen és honnan kezdödött a politika?

Biztos, hogy csalódást okozok, de semmilyen politikai behatást nem éreztem a szocializmusban eltöltött szolgálati éveim alatt. Lehet, hogy szerencsém volt, lehet, hogy a véletlen, de őszintén mondom, soha nem kísértett meg senki-később sem -, hogy bármit másképp gondoljak, mint ahogyan azt a törvényes eljárási rend szabályozta.

Izgalmas időben lett rendőrkapitány Dunaújvárosban. Rendszert változtatott az ország, de tudott-e rendszert változtatni a rendörség? Milyen kihívásokkal találkozott rendöri vezetöként a közbiztonságot érintöen, és milyen módon éreztette hatását a rendszerváltozás a szervezetben?

Biztosan szerencsém volt ebben is. Az emberi közösség nagyon jó volt az akkori kapitányságon, $\mathrm{s}$ a formális vezetővé válásomat megelőzően - ne tünjön szerénytelenségnek - nagyon erős informális elfogadottságom volt. A taxis blokádot követően ez tovább erősödött, hiszen a város megőrizte müködőképességét, tudható, hogy a nagy ipari üzemek folyamatos müszakban dolgoztak, az embereket a buszok folyamatosan kellett szállítsák a müszakos váltásokra, a várost el kellett látni élelmiszerrel stb. Szóval rendben ment minden. Ez pedig a város és a környező települések akkor frissen megválasztott önkormányzati vezetőinél erős partnerséget és bizalmat teremtett. A rendszerváltozást az jelentette, hogy fiatal vezetőként - 34 éves voltam akkor - mi tagadás eufórikus érzés volt újat teremteni, ez vitte a teljes kapitányságot előre. Jelentős munkateher-növekedés volt. Az a kapitányság, amelyik korábban 1200 körüli ismertté vált büncselekménnyel dolgozott évente, hónapokon belül évi 4600 ismertté válással kellett megbirkózzon. Rablások szinte 2-3 naponta, ugrásszerúen megnövekedő betöréses lopások, jármülopások és -feltörések. Rohantunk az események után. Nem volt elég jármü, nem volt informatikai háttér, bizonytalan volt a szakirányítás, az sem volt megengedett, hogy a közterületeken, a közutakon dinamikusan ellenőrizni lehessen. Ebben a nem várt terhelési rendszerben kellett megoldást találni, s egyenesen vezetett az út az informatika adta megoldások keresése felé. Akkor tanultam a Dunaferr egyik évben Év menedzserévé választott vezetőjétől, hogy: „Ha nincs pénz templomot építeni, a pusztában is lehet imádkozni!” Szóval magad uram...

Ennek az lett az eredménye, hogy az országban először itt volt a bünügyi munkát támogatni tudó, integrált bủnügyi feldolgozó rendszer. Idősebbek emlékezhetnek rá, a Dunamodul nevet viselte. Ezzel segítettünk a bünügyi oldalon, de hiányzott a közterületiek hatékonyabb irányítási rendszere. Nem volt trönkölt rádió rendszer, nem volt erőforrás-gazdálkodás, nem lehetett tudni, mi történik a közterületeken. Adódott a felismerés, hogy bevetésirányítási rendszer 
kell. Egyik kollégámmal, Bogár Tamással a saját költségünkön, önmagunknak szervezve meg a lehetőséget, elmentünk Karlsruhéba a német rendőrséghez a command and controll ${ }^{1}$ rendszert (ahogyan akkor a szakma nevezte, ez egyközpontú erőforrás-gazdálkodást jelent) tanulmányozni. Már az is csoda, hogy fogadtak bennünket, tanítottak, segítettek. Eldöntöttük, hogy ezt mi is meg tudjuk csinálni. Itthon aztán ez is megtörtént. Az egész ország rendőri vezetői Dunaújvárosba jártak korszerü rendőrséget tanulni. A lendület vitt minket, jó szövetségeseket találtunk, egy külső cég - a Medisoft Kft. - segített az informatikai fejlesztéseinkben, a város, valamint az ott dolgozó nagyüzemek pedig anyagilag is támogatták az eszközbeszerzéseinket. Ez ma már elképzelhetetlen lenne. Akikről mindenütt meg kell emlékezzek, ha ez a téma szóba kerül: Bogár Tamást említettem, utóbb ezredes, ma a kórház főigazgató Jenei Zoltán mellett dolgozik informatikai vezetőként a feladatok optimatizálásán, Szomor Sándor, aki ma már ezredes, a BM rendőri területek szakirányításán dolgozik, illetve Jenei Gyula, aki alezredesként ment nyugdíjba. Valamennyien nagyszerú emberek, és persze voltak sokan mások. Ami fontos: nemcsak kihívásokat élhettünk meg, hanem megoldásokat is tudtunk találni ezekre. Ennél nem sok több van.

Hogyan emlékszik vissza a Team Consult által végzett átvilágitásra és az önkormányzati rendörség kialakitása irányába mutató átszervezési törekvésekre? Elért bennünket is a gondolat. A kilencvenes évek elején jártunk, amikor küldöttség is jött hozzánk; Bencze József, aki akkor Nagykátán volt kapitányságvezető az akkori RTF egyik tanára, Szikinger István kíséretében - ő ma már magánügyvéd -, és az önkormányzati rendőrség mellett érvelve keresték a hasonlóképpen gondolkodó vezetőket. Ennél tovább azonban nem jutottunk. Tudom, hogy a rendszerváltozást követő belügyminiszterek közül többen voltak az önkormányzati rendőrség elkötelezettjei (dr. Horváth Balázs biztosan), de én ebben a tenyérnyi országban nem tudtam elképzelni a nem központosított, nem egyformán felszerelt, nem egy feladatrendszerben, nem egymást támogató szervezetekben dolgozó rendőrséget.

A Team Consult vizsgálat eredménye egy háromszavas javaslatban is összefoglalható: decentralizálás, demilitarizálás, depolitizálás. Miként látta ezt akkoriban? Szükséges kellékei ezek a rendörség fejlödésének? Ha igen, hogyan? Hol tartunk jelenleg?

Akkor kezdjük az elején! Könnyü volt azt mondani, hogy decentralizálni kell. Ez a kilencvenes évek elején azt jelentette, hogy az önkormányzatok átveszik

1 Parancsnoki irányító-ellenőrző tevékenység. 
a feladatok egy részét. Azt beszélték, hogy csak a bünügyi természetü feladatok, s talán a csapaterő maradnak az államnál, a közterületek rendjéért felelős erők az önkormányzatokhoz kerülnek. Meggondolatlanság volt. Gondolj bele, a csapaterőben kik szolgálnak ma is, ha szegény vagy gazdag az önkormányzat, ott szegény vagy jól felszerelt rendőrök látnak el szolgálatot. Mi lesz az információk begyüjtésével, ki, milyen módon fejleszt technológiát, mi lesz az informatikai lehetőségekkel? Sorolhatnám. Mi történik akkor, ha az ország minden rendőrének kell feladatot vállalni egy-egy ügyben? Gondolj bele, ilyen volt 2015-ben a határok védelme, ilyen ma a pandémia, de ilyen lehet egy jelentősebb biztosítási feladat is. Úgy megoldani egy nem várt, nagy erőt igénylö feladatot, hogy ahonnan elveszem az erőt, ott nem romolhat a közbiztonság, ahová pedig teszem, ott sikeres a feladat végrehajtása, ez csak központosítottan történhet. Divatos, s talán ma is olvasható, hogy militáns, autokrata szervezet vagyunk. Nem gondolom, hogy így van. A rendfokozat, az alakiasság valamiféle fennmaradása sokkal inkább a szervezeti kultúra része, az együvé tartozás kifejezése. Ilyenkor szoktam Kipling: A dzsungel könyve című munkáját idézni: „,Egy vérből vagyunk, te meg én!’ Ez növeli a szervezeti eröt, s ennek igenis vannak a megszokottól talán eltérő megnyilvánulásai is, de több előnye van, mint hátránya. Én sem voltam kezdettől fogva tábornok, de soha nem zavart egyetlen korábbi rendfokozatom vagy beosztásom aktuális állapota sem. Aztán arról is érdemben lehet beszélni, hogy ma Magyarországon a rendőrség az egyetlen regulárisan szervezett, érdemi élő erőt felvonultatni képes szervezet. Talán elég, ha a 2010. évi felső tiszai árvízre utalok. E nélkül hogyan lehetett volna 12-14 ezer kollégát 2-4 órán belül erre a feladatra mozgósítani?! Ami pedig a katonai típusú gondolkodásról alkotott kritikai észrevételeket illeti, azt gondolom, hogy például egy magas minőségü jármüszakszerviz vagy maga az autógyár legalább olyan vagy szigorúbb szabályok szerint múködik, ami a szabályok keménységét, következetességét illeti, uram bocsá', az ott dolgozók vezetéstől való függősége - meggyőződésem - erősebb, mint a rendőrségnél. És amiről rendre megfeledkeznek: a szabály a munkatársat is védi, ezer példát tudnék felsorolni. Végül a depolitizálás! Hogyan lehetne teljesen intakttá tenni, ha politikai pártok megválasztott képviselőinek a többsége hozza a törvényeket, ha választásokon győztes politikai pártok alakítanak kormányt, adják a tárcát felügyelő és érte felelősséget viselő minisztert, s mindezeket az ügyeket az ellenzék kontrollálja? Minden eddig felsorolt szereplő politikus. És mi a politika dolga? Nem az élhető viszonyok megteremtése, fenntartása?!

Azt is gondolom azonban, hogy a lojalitás elvárható kell legyen, a szervilizmus nem, s ebben az interjúban elmondhatom, hogy hosszú pályám alatt - de lehet, hogy szerencsém volt - soha senki nem sugallta, hogy mi volna a ,helyénvaló” 
eljárás adott ügyben vagy adott beszerzésben. Ez a rendszerváltást megelőzően is igaz volt! Tehát a kérdésre visszatérve: meggyőződésem, hogy a hivatásos életpályának a katonai típusú szervezeti kultúra használ, a decentralizációnak maga a világ fejlődése mond ellent.

Ez volt az az időszak, amikor a rendörség ,, egyeduralma” megszünt a közbiztonsági problémák kezelésében. Létrejött a polgárörség, kialakult az önkormányzatok rendészeti szerepe és egyre-másra alakultak a vagyonvédelmi vállalkozások, amelyek gyakran a rendörségtöl importálták a szakembereiket. Lehetöségként vagy veszélyként élte meg a rendészet pluralizálódását?

Amint fentebb már említettem, jelentős munkateher-emelkedéssel járt a rendszerváltozás, s ezt a döntéshozatalban nem egyszer bizonytalanság kísérte. Én akkor a polgárőrséget úgy fogadtam, mint egy nagyon jó kezdeményezést, de olyasvalami, mint ami a rendőri munka kritikájaként jött létre. Még nem teremtődtek meg az újonnan létrejövő magánvagyonok magánbiztonságának a feltételei. Ma ez már egyértelmü. Visszatérve, az önkormányzatok alakuló rendészeti szerepe nem volt több, mint önkormányzati törvényi mondat, és közbiztonságot támogatni célzó alapítványok forrásokkal való erősítése. Fenyegetést egyébként nem láttam ebben, tudható volt, hogy az államnak ezt a feladatát senki más nem láthatja el, s az igazgatás utóbb fel is nőtt ehhez a szinthez.

A rendészetet kutatók körében markánsan tartja magát a nézet, amely szerint az erösen hierarchizált szervezet minden tagját szolgai szerepre kényszeríti. Az ön pályája mintha ellenpróbája lenne ennek az állitásnak. A rendszert tágította vagy az elképzeléseit faragta rendszer-kompatibilisre?

Biztosan szokatlan lesz, amit erről gondolok, de ahogyan fent már jeleztem, soha nem kerestek meg egyik feladatomban sem, hogy politikailag „legyek megértö", de a mindenkori szabályok mellett mindig volt lehetôség valamit jobban csinálni. Lehet, hogy túlontúl reguláris a beállítódásom, de szabályok mindig vannak, s mindig ezek között kell az optimumra törekedni. A Nap keleten kel, s nyugaton nyugszik. Nem egyszerübb-e elfogadni, s hozzá igazítani a dolgainkat, mint küzdeni ellene? Ez persze nem jelenthet szervilizmust. Embernek kell maradni vezetőként is, és küldetés kell legyen segíteni mindenkinek, akinek lehet.

Kétszer lehetett megyei rendörfökapitány, két megyében két évtizednyi különbséggel. Kétféle rendörségen? Miben különbözött ez a két korszak?

Valóban, ez időben akkora távolság, hogy akár két különböző rendőrséget is láthatunk benne. Az első feladat Fejér megyében 1996 ösze és 2000 augusztusa között volt. Minden, amit a dunaújvárosi kapitányság kapcsán mondtam a terhek 
növekedése és az erőforrások közötti szakadék tekintetében, igaz volt. A második Zala megyében 2015 és 2020 novembere között jutalomjáték. Egyrészt én is tapasztaltabb lettem - sokat veszítettem korábban talán jellemző impulzivitásomból -, rengeteg többlettudás, tapasztalat állt rendelkezésemre, a személyes ismeretségek, ha tetszik, a kapcsolatok már egészen másképp müködtek. S az is nagyon fontos, hogy a mai rendőrség technikai, technológiai felkészültsége, ellátása, a munkatársak kiképzettségi szintje egészen más. Előnyére változott! Amit a kilencvenes években saját erőfeszítésből munkafeltételként meg kellett teremteni, az ma adott. Időközben letisztult, kiteljesedett a polgárörség szerepe, dedikált a magánbiztonság, tiszták a határok. Egyben nincs változás. Továbbra is a rendőrség egyfajta „ultima ratio-ként” felel a biztonságért, folyamatos készenlétben van a veszélyelhárítás érdekében. Ma talán erősebb az a felismerés, hogy a rendőr feladata az értékteremtés, s ma már általános az is, hogy a gazdasági életet pozitív módon befolyásolni képes a tevékenysége eredménye is.

\section{Milyen lehetőségei voltak arra, hogy a helyi problémákat helyi megoldások- kal kezelje?}

Azt gondolom, hogy ez ma is adott mindenkinek. A helyben keletkezö feladat fő szabályként helyben kell megoldódjon. A vezető dolga mindenütt az erőforrás-gazdálkodás optimalizálása. Ebbe persze benne van egy jól müködő teljes rendszer is a siker érdekében, mert például az ORFK koordinációs tevékenysége ettől elválaszthatatlan. Az azonban biztos, hogy a „nem érdekel, ez parancs, hajtsa végre" szemlélet végérvényesen a múlté. A világ ma olyan, hogy a rendőri vezető - miként egy vállalat vezetője is - azzal a feladattal kell megbirkózzon, hogy egységnyi költségvetési pénzből a legtöbb jó megoldást valósítsa meg. A cégtulajdonos ehhez képest egységnyi pénzből a lehető legtöbb profitot akarja. A különbség alig értelmezhető.

\section{A rendörség fö gazdasági vezetöjeként milyen lehetöségei voltak az innovativv szemlélet érvényesitésére?}

Amikor válság van, mindig az innováció a megoldás. Akkor lehettem a rendőrség gazdasági vezetője, amikor - ahogy akkor mondtam - életveszélyt elhárító költségvetésből kellett a mindennapokat finanszírozni. Ezzel együtt is, hála a nagyon sok jól felkészült munkatársamnak, ment a világ előre. Akkor lehetett a kiteljesedő informatikai rendszerben országosan új hálózati operációs rendszert megvalósítani. Új, trönkölt rádió rendszerre állt át a rendőrség, a mobil telefónia flottába szervezése megtörténhetett, a krónikus gépjármühiányt egy nagyon jó költségü bérautórendszerrel orvosolni lehetett, a rendőri szervek költségvetésének normásítása valóság lett. Ezen túl még az is belefért, hogy 
2013-ban a jelzetes rendőrautókon eldöntöttem a csíkot. Ekkor változott meg a megkülönböztetéses járművek megjelenése is. Ebben a periódusban történt a rendőrség és határőrség integrációja, s az átalakult szervezet gazdasági ellátása is alapvetően újult meg. Nem azért, mert a nevemhez is kötődik, de korszakos lehetőség volt a regionális ellátás megvalósításában. Sajnálom, hogy ebben visszalépés történt. Csak emlékeztetőként: nem nekem volt innovációs a szemléletem, hanem annak a szakmai körnek, akikkel dolgozhattam. A tisztesség kedvéért el kell mondanom, hogy gazdasági föigazgató elődöm, Jenei Zoltán is ezen az úton járt, s példaként említem, hogy akkor az innovációnak definiált szervezete volt az ORFK-n.

Egy évtizednyi gazdasági vezetői munka után a közmunkaprogram kialakitásából vette ki a részét. Civilként vagy rendörként tette a dolgát?

Itt is „csak” gazdálkodni kellett, s a küldetés az volt, hogy egységnyi pénzből legyen élet, iskola, fütés, iskolatáska s a meginduló jövő ott, ahol addig csak a nincs volt. Persze tartást adott a rendőri múltam, ha tetszik, a szocializációm, de a szabályok megtartása mellett dolgozni elv, aligha választja el a civil vagy a rendőri gondolkodást.

\section{Lehet hatással a közmunkaprogram a közbiztonságra?}

Meggyőződésem, hogy igen. A feladattalanság, a munka hiánya szétzilálja a társadalmat, élhetetlenné teszi, szegregáltságot (kirekesztést, elszigetelődést - a szerk.) okoz. Azt gondolom erről, hogy a korszerü társadalmak egyébként egyik korszakos kihívása, hogy miként tudnak lehetőleg a legtöbbeknek munkát, jövedelmet adni akkor, amikor a végezhető munkák száma - ha dologként tekintek rá - egészen biztosan csökken.

Melyek lehetnek azok a kompetenciák, amelyek a közbiztonsági problémák kezelésére, a közmunkaprogram müködtetésére és az egészségügy különleges jogrend során jelentkezö egyes feladatainak ellátására egyaránt alkalmassá teszik a rendört?

Nagyon nagymértékủ empátia biztosan kell hozzá. Szemléletben pedig tudni kell, hogy értéket teremtünk, bármi is a feladat. Egy olyan világban kell a rendőrnek naponta helyt állni, ahol nincs állandóság, s akkor is megoldást kell találnia, ha a gyorsabban változó társadalmi viszonyokat a szabályok utóbb követik csak. Bogár Tamás volt munkatársamat kell idéznem, aki az képviselte, ,, hogy csak olyan dolog történik velünk, ami ez idáig nem volt”. Ez igaz a mindennapokra is. Aki ezt megéli, az sikeres lehet. 
Az a negyven év, melyben rendörként szolgált, a rendörség és a társadalom viszonyában egyfajta útkeresésként is értelmezhetö. Ön hogyan látja ezt a folyamatot? Honnan indultunk, hol tartunk, és hová kellene eljutnunk?

A rendőrség nem monolit szervezet. Valamennyien tanultunk jogot, van, aki jogtudományt is. Egy rendőri vezető mindenkor abban a présben van, hogy a társadalmi viszonyok nagyon gyors változásait a jog csak jelentős késéssel tudja követni, miközben a felelőssége a közbiztonságért, az életviszonyok békéjéért naponta fennáll, $\mathrm{s}$ a rendőrség pedig nem cselekedhet a jog ellenére. Ez maga a fejlődés, ezt tapasztaltam 20-30 évvel ezelött is, ma is, csak ma folyamatosan, egyre gyorsuló módon! Igazi vezetői feladat a megfelelés! S honnan indultunk? El sem hiszik, munkába állásom első feladata az volt, hogy a városi BÁ V-nál (Bizományi Áruház Vállalat) megvettem azt az Optima típusú mechanikus írógépemet - saját pénzemen -, amivel 10 éven át dolgoztam. Ma az ország legkomplexebb informatikai rendszerén dolgoznak ezrek, közel 10 ezer darabos jármüpark áll rendelkezésre, s a világ egyik legkorszerübb kommunikációs rendszere támogatja a feladatok végrehajtását, 1,6 millió $\mathrm{m}^{2}$-t lakunk. Persze látszanak a közeli jövő kihívásai is. Azt gondolom, hogy a megyei rendőr-fökapitányságoknak adott feladatok megoldásában sokkal integráltabban kell végezniük a napi munkájukat. Látni nagyon jó kezdeményezéseket. Tovább kell, hogy erősödjön az ORFK ügyekhez kötődő koordinációs szerepe, a digitális nyomok feldolgozásában óriási, még ki nem használt lehetőségek vannak. A kollégák munkahelyi feltételeinek javítása soha nem érhet véget, sokkal intenzívebben kell támogatni az innovációt - ki kell gondolkodni a papírból -, a pályán lévők egészségi állapotának a lehető legjobb megőrzése rendkívül jelentős feladat, sok javítani való van a belső és külső kommunikáción stb. Soha nem lesz vége!

Hányféle rendörségen dolgozott? Mennyiben más ez a rendörség, mint a rendszerváltozás elötti?

Meglehet szokatlan lesz a válaszom vagy legalábbis nem csatlakozik az „elöző rendszerben minden rossz volt" gondolathoz. A közbiztonságról minden politikai mázt le kell venni. Ott, akkor mi valamennyien a köztörvényes büncselekményt elkövetőket akartuk felderíteni, s a jog útján a bíróság elé állítani. Ha nagyon belegondolunk, ma is ez történik.

Nyugdíjba vonulása után is fontos szerep vár önre a rendörségi kommunikáció területén. A feladat elején a tapasztalatokról talán még korai beszélni, ezért inkább azt kérdezem: mi a viziója a rendörség jövőbeni kommunikációs tevékenységéröl? A rendör minden tevékenysége kommunikáció. Elrontott intézkedést kommunikációval nem lehet meg nem történté tenni. Majd minden tettünk a nyilvánosság 
elött zajlik, mindenkinek minden rögzítésére alkalmas eszköz a zsebében van. Innen kezdve a rendőr színpadon dolgozik, s csak a felkészültség, a szakmai megalapozottság adhat biztonságot. Ezen túl pedig azt gondolom, hogy a ma nem mindenkor egy mederben folyó kommunikációs tevékenységet a szervezet egészében integrálttá kell tenni, s költségvetési érzékenységgel, mérésekkel ellenőrzötten lehet csak folytatni. A rendőri kommunikáció nem lehet öncélú, a rendőr nem gyárthat híreket, s sokkal inkább szürke eminenciása a világnak, mint ahogy ma azt sokan gondolják. Azt is gondolom, hogy a rendőrnek sokkal inkább szakszerünek, jogszerünek kell lennie, mintsem pillanatnyi kommunikációs előnyökért népszerünek. Ez hivatás, s csak a törvény rendjén müködhet. Ezzel együtt a vezetők kapcsán pedig azt gondolom, hogy az a helyes út, ha senki fejében nem keveredik össze a szervezet népszerüsége a sajátjával.

Ön a Nemzeti Közszolgálati Egyetem címzetes egyetemi docense. Hogyan lehet ma egymás hasznára a rendészettudomány és a rendörségi gyakorlat?

Alkalmasint hívnak előadni, vizsgáztatni. Amennyiben az egyetem vezetése azt gondolja, hogy az ismereteimmel segíteni tudok, szívesen teszem, de nem állok sorba feladatért.

\section{Mi az ön igazi büszkesége az elmúlt negyven évböl?}

Talán arra a felismerésre vagyok a legbüszkébb, hogy az elmúlt időben töretlenül élhetett bennem a hit, hogy lehet jó rendészeti igazgatást csinálni. Valahány helyen, ahol dolgozhattam, mindenütt voltak meghatározó ügyek, amelyeken érdemben tudtam változtatni. S talán mindenekelőtt van az a tény, hogy minden, a mai rendészetben meghatározó fejlesztéshez közöm lehetett, alakíthattam azokat.

\section{Merre kell mutasson egy ma fiatal rendör iránytüje?}

Iránytüt mutatni, adni, javasolni nagyon nehéz, s mindannyian másfélék vagyunk, de ha abban lehet hinni, akkor tenni is lehet azért, hogy minden nehéz feladat adta helyzetben, mindig van/legyen megoldás.

\section{A cikk APA szabály szerinti hivatkozása}

Budavári Á. (2021). „Embernek maradni és segíteni”. Interjú dr. Sipos Gyula ny. r. vezérőrnagygyal. Belügyi Szemle, 69(6),1075-1085. https://doi.org/10.38146/BSZ.2021.6.9 